\title{
EFFECT OF MANNAN OLIGOSACCHARIDE AND VITAMIN E SUPPLEMENTATION ON PRODUCTIVE PERFORMANCE OF LOCAL STRAIN LAYING HENS SUBJECTED TO OCHRATOXIN-A CONTAMINATION
}

\author{
R.A. Hassan*; El-Samra H.A. Abo Egla**; F.S.A. Ismail ${ }^{* *}$; Kh. Sherif** and Hanaa A. B. \\ Ibrahiem*
}

*Anim. Prod. Res. Inst., Agric. Res. Center, Ministry of Agriculture, Giza, Egypt.

**Poultry Prod. Dept., Fac. Agric., Mansoura Univ., Mansoura, Egypt.

\section{SUMMARY}

T $\mathrm{n}$ this study, mannan-oligosaccharide (MOS) and vitamin E (Dl- $\alpha$-tocopheryl acetate) were used as feed supplements to ameliorate the deleterious effect of ochratoxin-A (OTA) on laying hens productive performance and some blood constituents. A total of 180 Inshas hens, 28 weeks of age were randomly distributed according to diet supplementation into six groups ( 30 hens, each in 3 replicates) as follow. T1: was fed a hen diet without any supplementation (control); T2: was fed the control diet supplemented with $1 \mathrm{~g}$ MOS / kg diet; T3: was fed the control diet supplemented with $150 \mathrm{mg}$ vit. E / kg diet; T4: was fed the control diet contaminated with $1000 \mathrm{ppb}$ of OTA. While, T5: was fed the control diet contaminated with $1000 \mathrm{ppb}$ OTA and supplemented with $1 \mathrm{~g}$ MOS / kg diet; and T6 was fed the control diet contaminated with $1000 \mathrm{ppb}$ OTA and supplemented with $150 \mathrm{mg}$ vit. E / kg diet. Results showed that feed contaminated with OTA at $1000 \mathrm{ppb}$ (T4) significantly decreased egg production percentage and feed consumption compared with the control group (but feed conversion was not affected). On the other hand, addition of either MOS or vit. E can ameliorate the toxic effects of OTA on productive performance and meat quality of hens.

Keywords: Ochratoxin-A, mannan-oligosaccharide, vitamin E and local laying hens.

\section{INTRODUCTION}

The occurrence of mycotoxins produced by fungi present in the raw materials which are used in poultry feed, is the key reason of mycotoxicosis. Consumption of mycotoxins at a very low level can cause severe mycotoxicosis but it can also result in reduce immune and acquired resistance to infections (Dalcero et al., 1998). The presence of aflatoxin B2 and ochratoxin A in poultry feed ingredients and processed feed seems to pose a serious threat for local poultry industry (Anjum et al., 2011). On the basis of acute mean lethal dose and minimal growth inhibitory concentration, ochratoxin $\mathrm{A}$ is the most dangerous mycotoxin studied in chickens. The most effective indicator of ochratoxicosis in young broiler chickens is enlarged kidneys. Ochratoxicosis in young White Leghorn cockerels leads to acute nephrosis, hepatic degeneration and suppression of hematopoiesis. In laying hens, low concentration of ochratoxin results in delayed sexual maturity, poor egg production and reduced hatchability (Doupnik and Peckham, 1970).

Lately, Abddlhamid et al. (2002) demonstrated that the more promising and practical approaches to counteract mycotoxins are the use of organic and inorganic adsorbents and vitamin supplements to livestock feeds.

Some previous researches proved that the Bio-Mos® prebiotic product, which contains mannan oligosaccharides issued from the cell walls of the Saccharomyces cerevisiae yeast, could generate beneficial effects, such as combating against intestinal pathogens in birds and mammals, modulating the immune response and improving the intestinal mucosae structural integrity (Spring et al., 2000). Prebiotics may also improve the utilization of macro minerals in laying hens (Chen and Chen, 2004).

Vitamin $\mathrm{E}$ is an essential vitamin possessing an antioxidant activity. Vitamin $\mathrm{E}$ given at a level higher than the recommended doses can increase the number of antibody-producing cells and elevate antibody titers in chickens and mice (Hossain et al., 1998).

In this respect, the present study aimed to determine if the addition of MOS and vitamin E would ameliorate the deleterious effects of ochratoxin-A on laying hens performance. 


\section{MATERIALS AND METHODS}

An experiment was carried out at Sakha Animal Production Research Station, Animal Production Research Institute, Ministry of Agriculture, Egypt. The present study aimed to evaluate the effect of mannan-oligosaccharide (MOS) [commercially available as Bio Mos®, a nutritional supplement manufactured by Alltech, Inc. (Nicholasville, KY)] and vitamin E (Vit.E) supplementation on performance of laying hens subjected to ochratoxin A (OTA) contamination. A total number of 180 Inshas hens, 28 weeks of age were randomly distributed into 6 equal groups with 3 replicates each (10 hens). Birds fed the experimental diets, as follows; (1) control, basal diet; (2) basal diet plus $1 \mathrm{~g}$ MOS $/ \mathrm{kg}$ diet; (3) basal diet plus $150 \mathrm{mg}$ vitamin E / $\mathrm{kg}$ diet; (4) basal diet plus $1000 \mathrm{ppb}$ OTA / kg diet; (5) basal diet plus $1000 \mathrm{ppb}$ OTA plus 1 of MOS /kg diet; (6) basal diet plus $1000 \mathrm{ppb}$ OTA / kg diet plus $150 \mathrm{mg}$ vit. $\mathrm{E} / \mathrm{kg}$ diet.

The experimental period lasted 16 weeks. The experimental diets were formulated by adding tested materials to a basal diet (Table 1) to be isonitrogenous $(16 \% \mathrm{CP})$ and isocaloric $(2700 \mathrm{kcal} \mathrm{ME} / \mathrm{kg} \mathrm{diet})$ and to satisfy the nutrient requirements of local strains of laying hens, according to Agriculture Ministry Decree (1996). The basal diet did not contain detectable levels of ochratoxin or aflatoxin $(<1 \mu \mathrm{g} / \mathrm{kg} \mathrm{diet})$.

The birds were reared under the same managerial conditions in an open-sided house on floor. The photoperiod used in this study was 17 hours daily. Feed and water were offered ad libitum during the experimental period.

\section{Ochratoxin production:}

The OTA was produced from Aspergillus ochraceus, strain NRRL 3174 available at the Institute of Animal Health, Dokki, Cairo, Egypt, by culturing on wheat grain using a modified method of Trenk et al. (1971) as described by Hassan et al. (2012) and was quantified by high performance liquid chromatography (HPLC) as demonstrated by Bayman et al. (2002).

\section{Measurements:}

Birds were individually weighed at the beginning and at the end of the experimental period. Feed Intake (FI), egg production (EP \%), egg weight (EW) daily egg mass and feed conversion were recorded. Body weight change $=100 \mathrm{x}$ body weight gain/ final body weight.

\section{Serum biochemistry and OTA residue in the kidney, liver and breast muscle:}

At the end of experimental period,while birds were sacrificed, $3 \mathrm{ml}$ blood sample was taken and stored at $-20^{\circ} \mathrm{C}$ for serum analysis to determine effects of feeding ochratoxin-contaminated diets on blood chemistry as measured by total protein, albumin, globulin, uric acid, cholesterol, calcium, phosphorus, total lipids, and activities of alkaline phosphatase (ALP), aspartate aminotransferase (AST) and alanine aminotransferase (ALT) which were measured by using available commercial kits, purchased from Diamond Diagnostics Company, Egypt. The tissue samples like liver, kidneys and breast muscle were stored at $-20^{\circ} \mathrm{C}$ for OTA residues analysis by HPLC (Sizoo and Egmond, 2005).

\section{Statistical analysis:}

Data from all the response variables were subjected to one way analysis of variance (SAS, 2000). Variability with significantly different means were separated at $\mathrm{P} \leq 0.05$ using Duncan's multiple range test (Duncan, 1955).

\section{RESULTS AND DISCUSSION}

Results of feed intake (FI), body weight (BW) change, egg production, egg weight and egg mass and feed conversion ratio are shown in Table 2. Feeding Ochratoxin-A contaminated diets decreased daily feed consumption compared with the control group, while hen fed the diets supplemented with MOS or Vit E in absence of OTA recorded approximately similar means of body weight change, egg weight, egg production and feed intake to those of the control group. The lower feed intake with diet contaminated with OTA decreased egg mass production and average egg weight compared with the control group and other dietary treatments. However, there were no differences among treatments regarding feed-to-gain ratio. Incorporating MOS or vit. E into the OTA-contaminated diets partially ameliorated the adverse effects of OTA on daily feed consumption and egg production $(\% / \mathrm{hen})$. The OTA treatment showed the least egg production. The effects of dietary treatments on serum biochemistry are summarized in Table 3. 
Ochratoxin-A in the diet significantly increased the serum activities of alanine aminotransferase, aspartate aminotransferase, and ALP, and the serum concentration of uric acid, whereas it decreased the serum concentrations of total protein, creatinine, calcium and phosphorus (Table 3). In contrast, feeding MOS or vit. $\mathrm{E}$ in absence of OTA had no significant effect on serum biochemistry. A significant interaction between OTA and MOS or vit.E was observed in the serum concentrations of uric acid, and cholesterol; both MOS and vit. E effectively correct the negative effect of OTA on these blood constituents

Samples analyzed at the end of the experiment for residual OTA showed that OTA was mostly accumulated in the kidney, liver and meat in a descending order, respectively, (Table 4). Generally, it could be seen that the OTA-detoxifying agents, applied herein, significantly decreased accumulation of OTA in kidney, liver and breast meat. While, eggs gave negative results of residual OTA

The observed decrease in egg production coincided with reduced feed intake by the hens maintained on ochratoxin A (OTA) contaminated feeds, suggesting OTA-mediated toxicity. This decrease in the egg production is mainly due to a decrease in feed intake, poor health and perhaps decreases in protein synthesis, especially albumin. This hypothesis supported those of previous studies (Hassan et al., 2012).

The depression in productive performance occurred during ochratoxicosis in this study may be attributed to many factors. OTA affects protein synthesis through competitive inhibition of phenylalaninet-RNA-synthetase by phenylalanine moiety of the toxin (Bunge et al., 1978). Moreover, ochratoxin-A interferes with DNA, RNA and protein synthesis and affects carbohydrate metabolism, particularly glucogenolysis. Changes in the serum concentrations of several proteins and metabolites and the activity of certain enzymes can be used as sensitive indicators of ochratoxicosis (Marquardt and Frohlich, 1992). Biochemical signs of ochratoxicosis in poultry reported in the literature include decreases in seum total protein, albumin, globulin, cholestrol, and triglyceride levels, and increases in uric acid and creatinine levels and in the activities of serum cholinesterase and gamma glutamyl transferase (Huff et al., 1988).

The increase in ALT and AST values in birds fed diets contaminated with ochratoxin reported herein could be attributed to the hepatic damage caused by ochratoxin. The increased level of these two enzymes could be correlated to the degenerative changes noticed in the liver leading to leakage of enzyme into serum (Manafi, 2011).

In this study, significant $(\mathrm{P} \leq 0.05)$ increases were observed in serum creatinine and uric acid concentration in birds exposed to OTA in the diet. Similar observations attributable to ochratoxicosis have been reported by Kalorey et al. (2005) in these blood parameters. The observed increase in ALP activity is known to be indicative of hepatobiliary disease (Gentles et al., 1999). In fact, the reductions in serum cholesterol and triglycerides concentrations during ochratoxicosis may confirm an impaired liver metabolism (Kalorey et al., 2005). Feeding OTA-contaminated diets to laying hens in the present study significantly decreased serum calcium and phosphorus levels. Similar results were reported previously by Gupta et al. (2005).

In our study, significant amounts of OTA in were observed in the kidney and liver of all birds fed the contaminated diets. However, OTA residues were not detected in eggs when considering detection limits of $0.05 \mathrm{ng} / \mathrm{g}$. Similarly, Denli et al. (2008) reported no detection of OTA in eggs of laying hens fed diets containing 1 or $2 \mathrm{mg}$ of OTA $/ \mathrm{kg}$ diet.

\section{Efficacy of MOS and/or vit E:}

The most promising and economical approach for reducing mycotoxicosis in animal feeding is the use of adsorbents, which bind mycotoxins efficiently in the gastrointestinal tract and prevent their absorption (Dakovic et al., 2005). The in vitro biosorption of OTA by three yeast industry products: a vinasse containing yeast cell walls, a purified yeast $\beta$-glucan and a dried yeast cell wall fraction were studied (Ringot et al., 2005). Dried yeast cell wall fraction was reported to be the most efficient at adsorbing OTA. Several reports explained this phenomena by relating it to yeast $\beta$-D-glucans (Yiannikouris et al., 2006), glucomannans (Raju, and Devegowda, 2002) and mannanoligosaccharide (Oguz, and Parlat, 2004). At the same time, Santin et al. (2001) reported that cell wall of Saccharomyces cerevisiae improved the villus height in 7- day-old broiler chickens which might be the reason for their improved productive performance. The cell wall of yeast is normally constituted of mannan oligosaccharides and its use in young turkey poults has been shown to improve feed conversion of birds (Fritts and Waldroub, 2003).

Vitamin E, like other antioxidants, has been evaluated as a potent feed additive to decrease OTA toxicity in several species. Abdel-Wahhab et al. (2005) found that melatonin exhibits a preventive effect against OTA-induced oxidative stress and structural damage in the kidney through its role in the scavenging of free radicals and/or the prevention of lipid peroxidation. Grosse et al. (1997) demonstrated that OTA is implicated in DNA-adduct formation, and the incorporation of alpha-tocopherol in the diet decreased the renal DNA adduct (by 58\%) provoked by a single administration of OTA in mouse and rat kidney. 
When MOS or vit. E were incorporated into the OTA-contaminated diets, they increased egg production to levels comparable to that of the control, suggesting an ameliorating for the negative effects of the OTA on some serum variable such as serum concentrations of total protein, cholesterol, uric acid, and creatinine. These results along with the lower contents of OTA in the kidney and liver of birds fed the OTA + MOS or vit. E diets appear to support the suggestion that MOS or vit. E may provide protection tools against the toxic effects of OTA.

In conclusion, results of this study confirmed the toxic effects in laying hens of a prolonged dietary intake of OTA and the inclusion of MOS or vit. E, can significantly ameliorate many of such adverse effects.

Birds fed MOS or VE along with $1000 \mu \mathrm{g} / \mathrm{OTA}$ per $\mathrm{kg}$ diet showed productive performance and biochemical responses, almost similar to those of control birds suggesting a protective role of both compounds (MOS or VE) against OTA. These agents (substances) may be used as protective agents in poultry diets to meliorate the adverse effects of ochratoxin A if it is present in untolerable amounts.

Table (1). Chemical composition and calculated analysis of the basal experimental diet.

\begin{tabular}{|c|c|}
\hline Ingredients & $\%$ \\
\hline Yellow corn & 66.00 \\
\hline Soybean meal (44\%) & 24.00 \\
\hline Limestone & 7.59 \\
\hline Di-calcium phosphate & 1.71 \\
\hline Sodium chloride & 0.30 \\
\hline Vit.\& Min. Mixture* & 0.30 \\
\hline DL.Methionine & 0.10 \\
\hline Total & 100 \\
\hline \multicolumn{2}{|l|}{ Calculated analysis** } \\
\hline Metabolizable energy (kcal/kg) & 2750 \\
\hline Crude Protein, $\%$ & 16.43 \\
\hline Crude fiber, $\%$ & 3.20 \\
\hline Ether extract, \% & 2.70 \\
\hline Calcium, \% & 3.33 \\
\hline Available phosphate, $\%$ & 0.45 \\
\hline Total phosphorus, $\%$ & 0.66 \\
\hline Lysine, $\%$ & 0.86 \\
\hline Methionine, \% & 0.39 \\
\hline
\end{tabular}

Table (2). Efficacy of Mannan-Oligosaccharides (MOS) and vitamin E for detoxification of ochratoxin contaminated diets on productive performance of local laying hens during the experimental period (28-44weeks of age).

\begin{tabular}{|c|c|c|c|c|c|c|c|c|c|}
\hline Treatment & $\begin{array}{l}\text { Initial } \\
\text { body } \\
\text { weight, } \\
\text { (g) }\end{array}$ & $\begin{array}{c}\text { Final } \\
\text { body } \\
\text { weight, } \\
\text { (g) }\end{array}$ & $\begin{array}{l}\text { Body } \\
\text { weight } \\
\text { gain, } \\
\text { (g) }\end{array}$ & $\begin{array}{c}\text { Body } \\
\text { Weight } \\
\text { change, } \\
\%\end{array}$ & $\begin{array}{c}\text { Average } \\
\text { egg } \\
\text { weight, } \\
\text { g }\end{array}$ & $\begin{array}{l}\text { Egg mass } \\
\text { (g/hen/day) }\end{array}$ & $\begin{array}{c}\text { Egg } \\
\text { production } \\
\%\end{array}$ & $\begin{array}{c}\text { Feed } \\
\text { intake } \\
\text { (g/hen/day) }\end{array}$ & $\begin{array}{c}\text { Feed } \\
\text { conversion } \\
\text { (g.feed/g.egg) }\end{array}$ \\
\hline Control (C) & 1487.33 & $1686.33^{\mathrm{a}}$ & $199.00^{\mathrm{ab}}$ & $11.79^{\mathrm{ab}}$ & $50.57^{\mathrm{ab}}$ & $29.27^{\mathrm{a}}$ & $57.88^{a}$ & $94.08^{\mathrm{a}}$ & 3.21 \\
\hline MOS & 1474.83 & $1680.33^{\mathrm{ab}}$ & $205.50^{\mathrm{a}}$ & $12.22^{\mathrm{a}}$ & $50.67^{\mathrm{a}}$ & $29.59^{a}$ & $58.39^{\mathrm{a}}$ & $92.47^{\mathrm{ab}}$ & 3.12 \\
\hline Vitamin E & 1484.16 & $1683.16^{\mathrm{ab}}$ & $199.00^{\mathrm{ab}}$ & $11.82^{\mathrm{ab}}$ & $50.53^{\mathrm{ab}}$ & $29.49^{\mathrm{a}}$ & $58.36^{\mathrm{a}}$ & $92.23^{\mathrm{ab}}$ & 3.12 \\
\hline OTA & 1482.83 & $1585.33^{c}$ & $102.50^{\mathrm{d}}$ & $6.45^{\mathrm{d}}$ & $49.23^{\mathrm{d}}$ & $27.12^{\mathrm{b}}$ & $55.08^{\mathrm{b}}$ & $85.68^{d}$ & 3.15 \\
\hline OTA+MOS & 1480.16 & $1673.83^{a b}$ & $193.66^{\mathrm{b}}$ & $11.57^{\mathrm{b}}$ & $50.27^{c}$ & $29.02^{\mathrm{a}}$ & $57.73^{a}$ & $90.11^{b c}$ & 3.10 \\
\hline $\mathrm{OTA}+\mathrm{VE}$ & 1486.00 & $1668.83^{b}$ & $182.83^{c}$ & $10.95^{\mathrm{c}}$ & $50.49^{b}$ & $28.95^{\mathrm{a}}$ & $57.35^{\mathrm{a}}$ & $89.18^{c}$ & 3.05 \\
\hline SEM & 1.93 & 3.24 & 2.91 & 0.165 & 0.120 & 0.211 & 0.299 & 0.729 & 0.016 \\
\hline P-value. & 0.474 & 0.0001 & 0.0001 & 0.0001 & 0.0001 & 0.0001 & 0.0001 & 0.0001 & 0.244 \\
\hline
\end{tabular}


Table (3). Efficacy of Mannan-Oligosaccharides (MOS) and vitamin E for detoxification of ochratoxin contaminated diets on some blood constituents of local laying hens at the end of the experimental period.

\begin{tabular}{|c|c|c|c|c|c|c|c|c|}
\hline Itemies & $\begin{array}{l}\text { Control } \\
\text { (C) }\end{array}$ & MOS & Vit. E & OTA & $\begin{array}{c}\text { OTA } \\
+ \text { MOS }\end{array}$ & $\begin{array}{l}\text { OTA+ } \\
\text { Vit.E }\end{array}$ & SEM & $\begin{array}{c}\mathrm{P}- \\
\text { value. }\end{array}$ \\
\hline T. protein $(\mathrm{g} / \mathrm{dl})$ & $5.40^{\mathrm{ab}}$ & $5.63^{\mathrm{a}}$ & $5.60^{\mathrm{a}}$ & $5.06^{\mathrm{b}}$ & $5.36^{\mathrm{ab}}$ & $5.36^{\mathrm{ab}}$ & 0.057 & 0.026 \\
\hline Albumin ( g/dl ) & $2.56^{\mathrm{abc}}$ & $2.76^{\mathrm{ab}}$ & $2.80^{\mathrm{a}}$ & $2.60^{\mathrm{abc}}$ & $2.50^{\mathrm{c}}$ & $2.53^{\mathrm{bc}}$ & 0.038 & 0.003 \\
\hline Globulin ( g/dl ) & 2.83 & 2.86 & 2.80 & 2.46 & 2.86 & 2.83 & 0.056 & 0.299 \\
\hline Cholesterol ( $\mathrm{g} / \mathrm{dl})$ & $127.66^{\mathrm{ab}}$ & $123.00^{\mathrm{b}}$ & $125.00^{\mathrm{b}}$ & $140.33^{a}$ & $131.66^{\mathrm{ab}}$ & $138.00^{\mathrm{a}}$ & 2.04 & 0.040 \\
\hline Total Lipids ( mg/dl) & 14.33 & 15.00 & 13.33 & 17.00 & 15.00 & 15.00 & 0.383 & 0.119 \\
\hline $\operatorname{AST}(\mathrm{U} / \mathrm{L})$ & $42.66^{c}$ & $40.00^{c}$ & $40.00^{\mathrm{c}}$ & $57.00^{\mathrm{a}}$ & $47.33^{\mathrm{b}}$ & $48.66^{\mathrm{b}}$ & 1.500 & 0.0001 \\
\hline ALT( U/L) & $10.66^{\mathrm{c}}$ & $11.00^{c}$ & $11.66 b^{c}$ & $15.33^{\mathrm{a}}$ & $14.66^{\mathrm{ab}}$ & $13.66^{\mathrm{abc}}$ & 0.549 & 0.018 \\
\hline ALP( U/L) & $24.5^{\mathrm{c}}$ & $24.3^{\mathrm{c}}$ & $24.7^{\mathrm{c}}$ & $28.6^{\mathrm{a}}$ & $26.4^{\mathrm{b}}$ & $26.7^{b}$ & 1.20 & 0.0001 \\
\hline Uric acid ( $\mathrm{mg} / \mathrm{dl})$ & $4.60^{\mathrm{bc}}$ & $4.43^{c}$ & $4.63^{\mathrm{bc}}$ & $5.86^{\mathrm{a}}$ & $4.80^{\mathrm{bc}}$ & $4.90^{\mathrm{b}}$ & 0.120 & 0.0001 \\
\hline Creatinine $(\mathrm{g} / \mathrm{dl})$ & $0.453^{\mathrm{b}}$ & $0.450^{\mathrm{b}}$ & $0.466^{\mathrm{b}}$ & $0.556^{\mathrm{a}}$ & $0.486^{\mathrm{b}}$ & $0.486^{\mathrm{b}}$ & 0.010 & 0.004 \\
\hline $\mathrm{Ca}(\mathrm{mg} / \mathrm{dl})$ & $11.66^{\mathrm{a}}$ & $11.93^{\mathrm{a}}$ & $11.83^{\mathrm{a}}$ & $10.00^{\mathrm{c}}$ & $11.16^{\mathrm{b}}$ & $10.93^{\mathrm{b}}$ & 0.167 & 0.0001 \\
\hline $\mathrm{P}(\mathrm{mg} / \mathrm{dl})$ & $4.40^{\mathrm{ab}}$ & $4.50^{\mathrm{a}}$ & $4.46^{\mathrm{ab}}$ & $3.36^{\mathrm{d}}$ & $4.23^{b}$ & $3.93^{c}$ & 0.100 & 0.0001 \\
\hline
\end{tabular}

${ }^{a-d}$ Means in the same row with different superscripts, differ significantly ( $\left.P \leq 0.05\right)$.

Table (4). Ochratoxin-A residue (ng / g.) in kidney, liver and breast meat of hens at the end of the experimental period as affected by feeding ochratoxin diets without and with MannanOligosaccharides (MOS) or vitamin E.

\begin{tabular}{cccc}
\hline Treatment & Kidney & Liver & Breast meat \\
\hline Control & $0.00^{*}$ & 0.00 & 0.00 \\
OTA & $12.83^{\mathrm{a}}$ & $8.50^{\mathrm{a}}$ & $2.80^{\mathrm{a}}$ \\
OTA+MOS & $5.23^{\mathrm{b}}$ & $3.46^{\mathrm{b}}$ & $1.20^{\mathrm{b}}$ \\
OTA+Vit. E & $5.40^{\mathrm{b}}$ & $4.00^{\mathrm{b}}$ & $1.22^{\mathrm{b}}$ \\
SEM & 1.390 & 0.868 & 0.258 \\
P-value & 0.004 & 0.03 & 0.003 \\
\hline
\end{tabular}

${ }^{a-b}$ Means in the same column with different letters, differ significantly $(P \leq 0.05) .{ }^{*}$ No detecting of ochratoxin $\mathrm{A}$

\section{REFERENCES}

Abdelhamid, A.M.; M.A Ragab and A.F. El-Shaieb (2002). The use of Tafla or aluminosilicate for alleviating toxic effects of aflatoxin-contaminated diets of growing rabbits. Proc. $1^{\text {st }}$ Ann. Sc. Conf. Anim. \& Fish Prod., Mansoura Fac. Agric., 24\&25 ep., pp: 389-413.

Abdel-Wahhab, M.A.; M.M. Abdel-Galil and M. El Lithey (2005). Melatonin counteracts oxidative stress in rats fed an ochratoxin A contaminated diet. J. Pineal Res., 38, 130-135.

Agriculture Ministry Decree (1996). The standard properties for ingredients, feed additives and feed manufactured for animal and poultry. El-Wakaee El- Masria, Amirria Press Cairo, Egypt. No. 192, 1997. pp: 95.

Anjum, M.A.; A.W. Sahota; M. Akram and I. Ali (2011). Prevalence of mycotoxins in poultry feed ingredients in Punjab (Pakistan). The J. Anim. Pl. Sci., (21)2:117-120.

Bayman, P.; J.L. Baker; M.A. Doster; T.J. Michailides and N.E. Mahoney (2002). Ochratoxin production by Aspergillus ochraceus and Aspergillus Alliaceus. Appl Environ Microbiol, 68:2326-2329.

Bung, I.; G. Dirheimer; and R. Roschenthaler, (1999). In vivo and in vitro inhibition of protein synthesis in bacillus stearothermophilus by ochratoxin A. J. Biochem. and Biophys. Res. Communs., 83:398405.

Chen, Y.C. and T.C. Chen (2004). Mineral utilization in Layers as Influenced by Dietary Oligofructose and Inulin, Intl. J. of Poult. Sci., 3 (7):442-445.

Dakovic, A.; M. Tomasevic-Canovic; V.S. Dondur; G.E. Rottinghaus; V.S. Medakovic and S. Zaric (2005). Adsorption of mycotoxins by organozeolites. Colloids Surf. B Biointerfaces, 46:20-25.

Dalcero, A.; C. Magnoli; M. Luna; G. Ancasi; M.M. Reynoso; S. Chiacchiera; R. Miazzo and G. Palacio (1998). Mycoflora and naturally occurring mycotoxins in poultry feeds in Argentina. Mycopathol., $141: 37-43$ 
Denli, M.; J.C. Blandon; M.E. Guynot; S. Salado, and J.F. Perez, (2008). Efficacy of a New OchratoxinBinding Agent (OcraTox) to Counteract the Deleterious Effects of Ochratoxin A in Laying Hens. Poult. Sci., 87:2266-2272.

Doupnik, B. and J.C. Peckham (1970). Mycotoxicity of Aspergillus ochraceus to chikcs. Appl. Microbiol., 19:594-597.

Duncan, D.B. (1955). Multiple range and multiple F-Test, Biometrics, 11: 1-42.

Fritts, C.A. and P.W. Waldroup (2003). Evaluation of Bio- Mos® mannan oligosaccharides as a replacement for growth promoting antibiotics in diet for turkeys. Int. J. Poult. Sci., 2:19-22.

Gentles A.; EE. Smith; LF. Kubena; E. Duffus; P. Johnson; J. Thompson; RB. Harvey and TS. Edrington (1999). Toxicological evaluation of cyclopiazonic acid and ochratoxin A in broilers. Poult Sci., 78:1380-1384.

Grosse, Y.; L. Chekir-Ghedira; A. Huc; S. Obrecht-Pflumio; G. Dirheimer; H. Bacha and A. PfohlLeszkowicz (1997). Retinol, ascorbic acid and alpha-tocopherol prevent DNA adduct formation in mice treated with the mycotoxins ochratoxin A and zearalenone. Cancer Lett., 114:225-229.

Gupta, S.; M. Jindal; R.S. Khokhar; A.K. Gupta; D.R. Ledoux and G.E. Rottinghaus (2005). Effect of ochratoxin A on broiler chicks challenged with Salmonella gallinarum. Br. Poult. Sci., 46:443-450.

Hassan, Z.U.; M.Z. Khan; A. Khan; I. Javed; U. Sadique and M.R. Hameed (2012). Effect of ochratoxin a (OTA)-contaminated feed on several health and economic parameters in white leghorn cockerels. Pak Vet J, 32:35-40.

Hossain, S.M.; S.L. Barreto; A.G. Bertechini; A.M. Rios and C.G. Silva (1998). Influence of dietary Vitamin E level on egg production of broiler breeders, and on the growth and immune response of progeny in comparison with the progeny from eggs injected with Vitamin E. Anim Feed Sci. Tech., 73:307-317.

Huff, W.E.; L.F. Kubena and R.B. Harvey (1988). Progression of ochratoxicosis in broiler chickens. Poult. Sci., 67:1139-1146.

Kalorey, D.R.; N.V.S. Kurkure; J.S. Ramgaonkar; P.S. Sakhare; S. Warke and N.K. Nigot (2005). Effect of polyherbal feed supplement "Growell" during induced aflatoxicosis, ochratoxicosis and combined mycotoxicosis in broilers. Asian-Aust. J. Anim. Sci., 18:375-383.

Manafi, M. (2011). Ochratoxin-A and Citrinin Induced Biochemical Changes in Broiler Chicken. Advances in Environmental Biology, 5(13):3775-3781.

Marquardt, R.R. and A.A. Frohlich (1992). A review of recent advances in understanding ochratoxicosis. J. Anim. Sci., 70:3968-3988.

NRC (1994). Nutrient requirements of chickens. In: Nutrient requirements of poultry (9th Ed.) National Academy of Science Washington D. C., pp. 9-26.

Oguz, H. and S.S. Parlat (2004). Effects of dietary mannanoligosaccharide on performance of Japanese quail affected by aflatoxicosis. S. Afr. J. Anim. Sci., 34:144-148.

Raju, M.V.I.N. and G. Devegowda (2002). Esterified-Gluco-mannan in broiler chickens dietscontamimated with aflatoxin, ochratoxin and T-2toxin: Evaluation of its binding ability (in vitro) and efficacy as immunomodulator. Asian-Aust. J. Ani. Sci., 15: 1051-1056.

Ringot, D.; B. Lerzy; J.P. Bonhoure; E. Auclair; E .Oriol and Y. Larondelle (2005). Effect of temperature on in vitro ochratoxin A biosorption onto yeast cell wall derivatives. Process Biochem., 40: 30083016.

Santin, E.; A. Maiorka; M. Macari; M. Grecco; J.C. Sanchez; I.M. Okada and A.M. Myasaka (2001). Performance and intestinal mucosa development of broiler chicken fed diets containing saccharomyces cerevisiae cell wall. J. Appl. Poultry Re., 10:236-244.

SAS (2000). SAS User's guide: Statistics. SAS Inst. Inc., Cary, NC.

Sizoo, E.A. and H.V. Egmond, (2005). Analysis of duplicate 24-hour diet samples for aflatoxin B1, aflatoxin M1 and ochratoxin A. Food Addit Conta, 22:163-172.

Spring, P.; C. Wenk; K.A. Dawson and K.E. Newman (2000). The effects of dietary mannan oligosaccharides on cecal parameters and the concentrations of enteric bacteria in the ceca of Salmonella-challenged broiler chicks. Poult. Sci., 79: 205-211.

Yiannikouris, A.; G. Andre; L. Poughon; J. Francoi,; C.G. Dussap; G. Jeminet; G. Bertin and J.P. Jouany (2006). Chemical and conformational study of the interactions involved in mycotoxin complexation with D-glucans. Biomacromolecules, 7:1147-1155. 
تأثير اضافة المانان أوليجوسكاريد وفيتامين هـ على الأداء الانتاجى لسلالة من الاجاج المحلى البياض المعرض

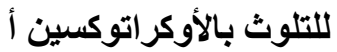

\author{
رضا على حسن*، السمرة حسن على ابوعجلة**، فوزى صديق عبدالفتاح أسماعيل*** و خليل الثحات شريف***، \\ و هناء عوض بسيونى ابراهيم*

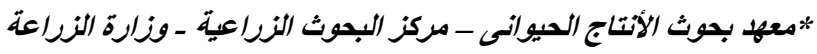

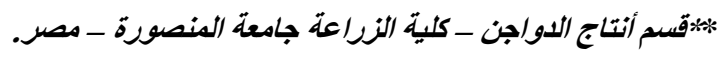

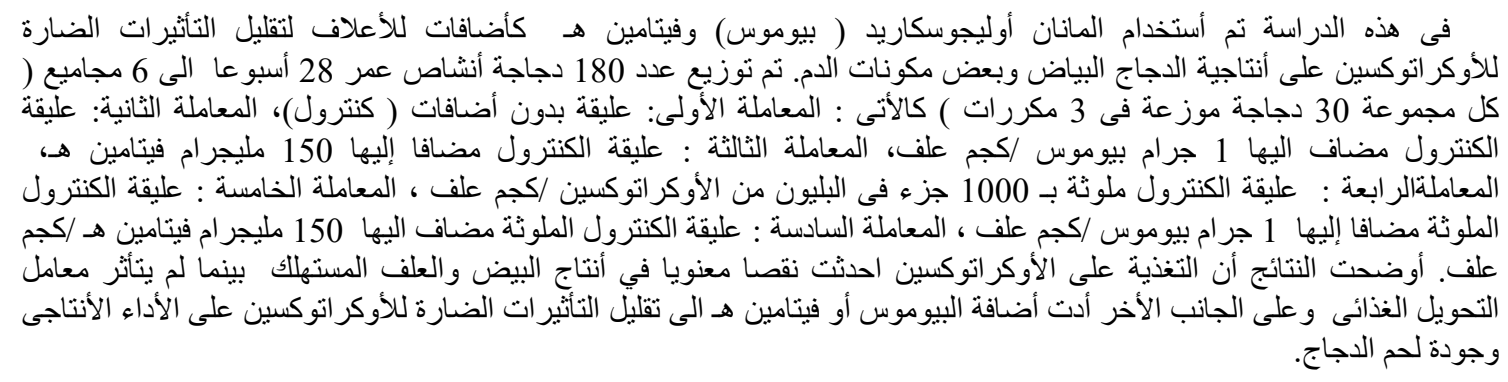

